\title{
Deskripsi Kemampuan Pemecahan Masalah Matematika Siswa Ditinjau dari Tipe Kepribadian Menurut Keirsey
}

\author{
Awi ${ }^{1, a)}$, Usman Mulbar ${ }^{1, b)}$, dan Sahriani ${ }^{1, c)}$ \\ ${ }^{1}$ Jurusan Matematika, Fakultas Matematika dan Ilmu Pengetahuan Alam \\ Universitas Negeri Makassar \\ a) awidassa@gmail.com \\ b) u.mulbar@unm.ac.id \\ c) sahriani212@gmail.com
}

\begin{abstract}
Abstrak. Penelitian ini bertujuan untuk mendeskripsikan kemampuan pemecahan masalah matematika siswa dengan langkah Polya (memahami masalah, menyusun rencana, melaksanakan rencana dan menelusuri kembali) ditinjau dari tipe kepribadian menurut Keirsey. Penelitian ini merupakan penelitian kualitatif-deskriptif. Subjek penelitian sebanyak 4 orang dari siswa kelas XI SMA dengan satu subjek untuk masing-masing tipe kepribadian. Instrumen penelitian menggunakan instrumen penggolongan tipe kepribadian, tes pemecahan masalah, dan pedoman wawancara. Hasil penelitian menunjukkan bahwa dari masing-masing siswa yang bertipe kepribadian Keirsey, dalam memecahkan masalah matematika lebih cenderung pada siswa yang bertipe kepribadian Guardian dan Rational, dapat melakukan setiap tahapan pemecahan masalah Polya. Selanjutnya adalah tipe Idealist dan Artisan yang masih kurang pada tahap pemecahan masalah tertentu dari permasalahan yang diberikan.
\end{abstract}

Kata Kunci : Pemecahan Masalah, Matematika Sekolah, Langkah Polya, Kepribadian Keirsey, Soal Non Rutin.

\begin{abstract}
This study aims to describe the student's ability to solve mathematical problems with Polya's steps (understanding the problem, devising a plan, carrying out the plan and looking back,) viewed from personality types according to Keirsey. This research is descriptive-qualitative. The research subjects were 4 students from class XI of Senior High School, with one subject for each personality type. The research instrument uses personality type classification instruments, problem-solving tests, and interview guidelines. The results of the research showed that from each of the students with the type of Keirsey personality, in solve mathematical problems more tend to be on types of Guardian and Rational personalities, can do every step of Polya's problem-solving. Next, are the Idealist and Artisan types which are still lacking at the steps certain solving the problem of the problems given.
\end{abstract}

Keywords: Problem Solving, School Mathematics, Polya's Steps, Keirsey's Personality, Non-Routine Problems.

\section{PENDAHULUAN}

Pemecahan masalah merupakan bagian dari kurikulum matematika yang sangat penting. Hal ini dikarenakan siswa akan memperoleh pengalaman dalam menggunakan pengetahuan serta keterampilan yang dimiliki untuk menyelesaikan soal. Salah satu tujuan pembelajaran matematika di sekolah adalah agar siswa memiliki kemampuan untuk memecahkan permasalahan sehari-hari. Pemecahan masalah matematika membuat matematika tidak 
kehilangan maknanya, sebab suatu konsep atau prinsip akan bermakna kalau dapat diaplikasikan dalam pemecahan masalah.

Tidak dapat dipungkiri bahwa setiap siswa mengalami kesulitan dalam belajar matematika sekolah, lebih khusus jika diberikan soal berbentuk pemecahan masalah. Kesulitan siswa yang berbeda-beda, mengakibatkan kemampuan siswa dalam memecahkan masalah matematika juga berbeda-beda sehingga salah satu tujuan pembelajaran matematika yaitu pemecahan masalah tidak tercapai dengan maksimal.

Perbedaan kemampuan siswa dalam menyelesaikan pemecahan masalah matematika bisa juga disebabkan karena perbedaan karakteristik yang dimiliki oleh setiap individu. Salah satu karakteristik tersebut adalah tipe kepribadian. Ayadi, Chatterjee \& Woldie (2006) mendefinisikan tipe kepribadian sebagai gambaran bagaimana seseorang mengambil informasi dan bagaimana seseorang membuat keputusan. Pemahaman terhadap suatu informasi, pengambilan keputusan, dan pemecahan masalah merupakan proses kognitif yang saling berhubungan.

Berpangkal pada kenyataan bahwa kepribadian manusia sangat bermacam-macam, bahkan mungkin sama banyak dengan banyaknya orang. Para ahli berusaha menggolongkan manusia ke dalam tipe-tipe tertentu, karena mereka berpendapat bahwa cara itulah yang paling efektif untuk mengenal sesama manusia dengan baik. Pada tahun 1984, Keirsey seorang professor dalam bidang psikologi dari California State University dalam bukunya Please Understand Me I dan II, menggolongkan kepribadian menjadi 4 tipe, yaitu Idealist, Rational, Artisan dan Guardian.

Menyadari akan pentingnya pemecahan masalah matematika dalam dunia pendidikan matematika dan adanya perbedaan kondisi pada masing-masing siswa, maka pengajar tentu harus mengusahakan agar siswa mencapai hasil yang optimal dalam menguasai keterampilan pemecahan masalah dengan menggunakan cara atau teknik mengajar matematika terbaik untuk masing-masing pribadi siswa. Hal ini dimaksudkan agar terjadi interaksi antara pengajar dan siswa. Interaksi akan terjadi bila menggunakan cara atau teknik mengajar matematika yang disusun secara sistematik dan logik ditinjau dari segi hakikat matematika dan segi psikologiknya yang disebut metode mengajar matematika.

Pengetahuan guru tentang kemampuan siswa dalam menyelesaikan masalah matematika merupakan hal yang penting. Dengan mengetahui proses/langkah-langkah yang dilakukan siswa dalam memecahkan masalah, guru dapat melacak letak dan jenis kesalahan yang dilakukan oleh siswa. Kemampuan pemecahan masalah dapat diselidiki melalui proses berpikir siswa dalam memecahkan masalah berdasar tipe kepribadian yang telah dikelompokkan berdasar pengelompokan oleh David Keirsey. Untuk mengetahui pemikiran seorang siswa mengenai pengerjaannya terhadap soal tertentu, tentunya bukan dilihat dari tingkah lakunya, akan tetapi secara spesifik dari hasil pekerjaan siswa. Untuk dapat mengetahui pemikiran seorang siswa, salah satunya dapat dengan cara mengajak siswa untuk berdiskusi dengan pengajar, sehingga siswa mau mengatakan apa yang ada dalam pemikirannya pada saat mengerjakan soal tertentu.

Penelitian ini bertujuan untuk mengetahui bagaimana deskripsi kemampuan pemecahan masalah matematika siswa kelas XI di salah satu SMA ditinjau dari tipe kepribadian menurut Keirsey. Dengan mengetahui kemampuan dan pemikiran siswa, maka diharapkan segala sesuatunya akan berjalan dengan lancar.

\section{KAJIAN PUSTAKA}

\section{Kemampuan Pemecahan masalah matematika}

Masalah dipandang sebagai alat untuk mencapai tujuan tertentu. Stanic \& Kilpatrick (1988) mengatakan bahwa masalah sebagai alat untuk mencapai tujuan kurikulum memiliki lima peran, yaitu: sebagai dasar pembenaran untuk pengajaran matematika, memberikan motivasi khusus 
pada topik mata pelajaran, sebagai rekreasi, sebagai alat mengembangkan keterampilan baru dan sebagai praktik.

Hudoyo (1979) menyatakan bahwa sesuatu disebut masalah bagi peserta didik, jika : pertanyaan yang dihadapkan kepada peserta didik harus dapat dimengerti oleh peserta didik tersebut, namun pertanyaan itu harus merupakan tantangan baginya untuk menjawab, dan pertanyaan tersebut tidak dapat dijawab dengan prosedur rutin yang telah diketahui peserta didik. Syaratsyarat masalah matematika yang sesuai dengan siswa yaitu; (1) bersifat menantang untuk diselesaikan dan dapat dipahami siswa, (2) tidak dapat diselesaikan secara langsung dengan prosedur yang biasa dikuasai siswa, dan (3) melibatkan materi atau konsep matematika (Rahimayanti, 2016).

Masalah adalah suatu keadaan dimana keadaan tersebut belum ditentukan cara penyelesaiannya, bersifat tidak rutin, dan menimbulkan rasa tertantang untuk menyelesaikannya serta memegang peran sebagai sarana untuk mencapai tujuan tertentu dalam kurikulum. Sedangkan masalah matematika dalam penelitian ini adalah soal yang bersifat non rutin yang berupa soal cerita serta belum secara langsung diketahui prosedur pemecahannya untuk menentukan solusinya, melainkan melalui strategi berpikir, perencanaan dan langkah-langkah pemecahan. Jika peserta didik menemukan aturan tertentu untuk menjawab pertanyaan atauuntuk mengatasi kesenjangan yang dihadapi, maka peserta didik tersebut sudah menyelesaikan masalah atau sudah memperoleh pemecahan masalah.

Pengertian sederhana dari pemecahan masalah adalah proses penerimaan masalah sebagai tantangan untuk menyelesaikannya. Pemecahan masalah merupakan bagian dari proses berpikir. Polya (1957) mendefinisikan bahwa pemecahan masalah sebagai usaha mencari jalan keluar dari suatu kesulitan. Menurut Polya (1957), langkah pemecahan masalah meliputi: memahami masalah (understanding the problem), menyusun rencana pemecahan masalah (devising a plan), melaksanakan rencana (carrying out the plan), dan menelusuri kembali (looking back).

TABEL 1. Indikator Kemampuan Pemecahan Masalah Berdasarkan Tahap Pemecahan Masalah oleh Polya.

\begin{tabular}{|c|c|}
\hline $\begin{array}{l}\text { Tahap Pemecahan } \\
\text { Masalah oleh Polya }\end{array}$ & Indikator \\
\hline Memahami masalah & $\begin{array}{l}\text { Siswa dapat menetukan hal-hal yang diketahui dan } \\
\text { ditanyakan. }\end{array}$ \\
\hline $\begin{array}{l}\text { Menyusun rencana } \\
\text { pemecahan masalah }\end{array}$ & $\begin{array}{l}\text { Siswa memiliki rencana pemecahan masalah } \\
\text { dengan menulis model/ rumus matematika dan } \\
\text { memilih suatu strategi yang dapat digunakan } \\
\text { sebagai pedoman dalam menyelesaikan masalah. }\end{array}$ \\
\hline Melaksanakan rencana & $\begin{array}{l}\text { Siswa melakukan langkah-langkah penyelesaian } \\
\text { berdasarkan rencana/strategi pemecahan masalah. }\end{array}$ \\
\hline $\begin{array}{l}\text { Menelusuri/Memeriksa } \\
\text { kembali }\end{array}$ & $\begin{array}{l}\text { Siswa menelusuri kebenaran hasil atau jawaban dan } \\
\text { menjelaskan atau menginterpretasikan hasil sesuai } \\
\text { permasalahan asal. }\end{array}$ \\
\hline
\end{tabular}

Tabel 1 menunjukkan indikator kemampuan pemecahan masalah berdasarkan langkah Polya yang menjadi acuan dalam penelitian ini. Salah satu fungsi utama pembelajaran matematika adalah untuk mengembangkan kemampuan pemecahan masalah. Kemampuan pemecahan masalah matematika siswa ditekankan pada berfikir tentang cara memecahkan masalah dan memproses informasi matematika. Sehingga, kemampuan pemecahan masalah matematika adalah pemahaman kognitif mengurai dan menjelaskan segala ide, informasi dengan proses berfikir yang dimiliki seseorang ketika menyelesaikan suatu masalah matematika. 


\section{Tipe Kepribadian Menurut Keirsey}

Pada tahun 1978, Keirsey mempublikasikan teorinya tentang penggolongan kepribadian dalam empat tipe kepribadian. Menurut Keirsey (1998) kepribadian digolongkan menjadi empat tipe, yaitu guardian (the epimethean temprament), artisan (the dionysian temprament), rational (the promethean temprament), dan idealist (the apollonial temprament). Penggolongan ini didasarkan pada bagaimana seseorang memperoleh energinya extrovert dan introvert, bagaimana seseorang mengambil informasi sensing atau intuitive, bagaimana seseorang membuat keputusan thinking atau feeling, dan bagaimana gaya dasar hidupnya judging atau perceiving.

Keirsey (2009) menggolongkan cara berkomunikasi baik lisan maupun tertulis menjadi dua kategori, yaitu concrete dan abstract, guardian dan artisan termasuk dalam kategori concrete, yaitu lebih menyukai berbicara dan menulis secara detail, spesifik, empiris dan faktual tentang realita, menyukai fakta, angka dan bukti, sedangkan idealist dan rational termasuk dalam kategori abstract, yaitu lebih menyukai berbicara dan menulis secara skematik, umum, teoritis dan fiksi tentang ide-ide, menyukai teori dan hipotesis. Selanjutnya, Keirsey menggolongkan cara memilih jalan/tindakan untuk menyelesaikan masalah menjadi dua, yaitu cooperative dan utilitarian, guardian dan idealist termasuk dalam kategori cooperative, dimana mereka akan memilih cara yang umum digunakan dan diterima kebanyakan orang, sedangkan artisan dan rational termasuk dalam kategori utilitarian, dimana mereka akan mencari cara yang paling efektif menurut mereka tanpa memikirkan apakah cara tersebut dapat diterima orang lain atau tidak (Kasriana, 2017).

Keirsey \& Bates (1978) mendeskripsikan masing-masing tipe kepribadian. Tipe guardian menyukai kelas dengan model tradisional beserta prosedur yang teratur. Siswa dengan tipe ini menyukai pengajar yang dengan gamblang menjelaskan materi dan memberikan perintah secara tepat dan nyata. Sebelum mengerjakan tugas, tipe guardian menghendaki instruksi yang mendetail.

Tipe artisan menyukai perubahan dan tidak tahan terhadap kestabilan, akan bekerja dengan keras apabila dirangsang dengan suatu konteks, segala sesuatunya ingin dikerjakan dan diketahui secara cepat, cenderung spontan menerapkan suatu penyelesaian yang baru ditemukan, bahkan cenderung terlalu tergesa-gesa dan kurang teliti. Artisan akan cepat bosan pada suasana yang menuntutnya terlalu fokus dan banyak berpikir.

Tipe rational menyukai penjelasan yang didasarkan pada logika. Mereka mampu menangkap abstraksi, cenderung lebih cepat dalam mengamati masalah, dalam menjalankan strategi dengan sistematis dan runtun setelah diberikan materi oleh guru. Tipe idealist lebih menyukai untuk menyelesaikan tugas secara pribadi daripada diskusi kelompok, menyukai membaca, dan juga menyukai menulis serta dapat memandang persoalan dari berbagai perspektif.

Hasil pengamatan terhadap kemampuan dan proses berpikir siswa akan membuahkan suatu kesimpulan bahwa setiap siswa selalu mempunyai perbedaan. Hal ini karena kemampuan dan proses berpikir siswa dipengaruhi oleh kepribadian siswa. Beberapa penelitian sebelumnya yang relevan dan menunjukkan hal tersebut, yaitu: penelitian yang dilakukan oleh Hamidah \& Suherman (2016) yang menunjukkan bahwa dari masing-masing siswa yang bertipe kepribadian Keirsey dalam memecahkan masalah matematika lebih cenderung pada siswa yang bertipe kepribadian guardian, dan penelitian yang dilakukan oleh Ilmiyana (2018) yang menunjukkan bahwa tipe kepribadian yang memiliki kemampuan pemecahan masalah matematis yang paling baik yaitu tipe kepribadian rational. 


\section{METODE PENELITIAN}

Penelitian ini merupakan penelitian kualitatif dengan pendekatan deskriptif, penelitian dilaksanakan di kelas XI pada salah satu SMA. Subjek penelitian terdiri dari 4 subjek, masingmasing satu subjek dari setiap tipe kepribadian menurut Keirsey yaitu subjek tipe guardian (SG), rational (SR), idealist (SI) dan artisan (SA). Instrumen yang digunakan yaitu instrumen penggolongan tipe kepribadian berupa angket, instrumen lembar tugas menyelesaikan masalah matematika berupa soal uraian dan instrumen pedoman wawancara yang telah divalidasi oleh dua orang ahli. Teknik pengumpulan data dalam penelitian ini, yaitu pemberian angket untuk pemilihan subjek penelitian, tes uraian yang digunakan untuk mengetahui kemampuan pemecahan masalah matematika siswa/subjek terpilih, kemudian wawancara digunakan untuk menggali data-data kemampuan pemecahan masalah matematika siswa guna memeperjelas data hasil tes uraian, yang tidak semunya dapat dijelaskan melalui analisa hasil jawaban tes uraian siswa, dan dokumentasi berupa rekaman suara pada saat wawancara.

Pengambilan data dalam penelitian ini dimulai dengan pemberian angket penggolongan tipe kepribadian kepada siswa kelas XI MIPA, kemudian mengelompokkan siswa ke dalam 4 tipe kepribadian berdasarkan hasil angket dan memilih 1 subjek dari masing-masing tipe kepribadian. Langkah selanjutnya, pemberian tes tertulis pemecahan masalah matematika, kemudian menganalis jawaban subjek dan mengadakan wawancara kepada 4 subjek terpilih berkaitan dengan lembar jawaban pemecahan masalah yang telah dibuat. Data dari hasil tes tertulis dan wawancara dipilah/dikategorisasi ke dalam setiap langkah pemecahan masalah Polya, kemudian dideskripsikan. Data hasil penelitian disajikan dalam bentuk deskriptif yang berisi uraian tentang kemampuan pemecahan masalah matematika siswa/subjek tipe kepribadian idealist, rational, artisan dan guardian, pada setiap langkah pemecahan masalah Polya. Terakhir adalah penarikan kesimpulan.

\section{HASIL DAN PEMBAHASAN}

Pada bagian ini dipaparkan data hasil penelitian, yaitu deskripsi kemampuan pemecahan masalah matematika siswa ditinjau dari tipe kepribadian menurut Keirsey.

\section{Subjek Tipe Guardian (SG)}

\section{Tahap Memahami Masalah}

Berikut ini disajikan hasil tes dan petikan wawancara subjek SG tahap memahami masalah.

$$
\begin{aligned}
& \Rightarrow \text { Edi dan ofi } 36 \text { jam }=1 \text { Pekerjaan } \\
& \Rightarrow \text { Edi dan Anwaril } 18 \text { jam }=1 \text { pekerjaan } \\
& \Rightarrow \text { Ofi dan Anwaril } 24 \text { jam }=1 \text { pekejaan }
\end{aligned}
$$

GAMBAR 1. Jawaban subjek SG tahap memahami masalah

Pada Gambar 1 terlihat subjek SG menuliskan hal-hal yang diketahui, namun tidak menuliskan hal yang ditanyakan. Untuk mengetahui pemahaman subjek SG tentang apa yang diketahui dan ditanyakan, maka dilakukan wawancara. Cuplikan wawancara subjek SG dijelaskan pada Transkrip 1:

\section{TRANSKRIP 1}

$P \quad$ : Coba jelaskan apa yang diketahui pada soal 2?

$S G_{01}$ : Berdasarkan soal ada 3 orang pekerja disini, Edi, Ofi dan Anwaril. Edi dan Ofi 
bekerja dalam waktu 36 jam, Edi dan Anwaril bekerja dalam waktu 18 jam, Ofi dan Anwaril bekerja dalam waktu 24 jam, untuk menyelesaikan 1 pekerjaan.

$P \quad: \quad$ Kemudian apa yang ditanyakan di soal?

$S G_{02}$ : Yang ditanyakan, waktu yang diperlukan untuk Edi, Ofi dan Anwaril untuk menyelesaikan pekerjaan secara bersama-sama.

Pada Transkrip 1, menunjukkan bahwa subjek SG mampu menguraikan dengan benar hal-hal yang diketahui $\left(S G_{01}\right)$ dan hal-hal yang ditanyakan dari soal $\left(S G_{02}\right)$, dengan penjelasan berdasarkan apa yang subjek SG pahami, sesuai dengan apa yang dimaksud pada soal.

\section{Tahap Menyusun Rencana Pemecahan Masalah}

Berikut ini disajikan petikan wawancara dengan subjek SG tahap menyusun rencana pemecahan masalah.

\section{TRANSKRIP 2}

$P \quad: \quad$ Selanjutnya apa yang dilakukan untuk menyelesaikan soal?

$S G_{03}$ : Pertama, dimisalkan $x$ adalah banyaknya pekerjaan yang diselesaikan Edi dalam 1 jam, kemudian y adalah banyaknya pekerjaan yang diselesaikan Ofi dan z adalah banyaknya pekerjaan yang diselesaikan Anwaril.

$P \quad: \quad$ Nah, bagaimana selanjutnya?

$S G_{04}: \quad$ Menyusun persamaannya kak.

$P \quad: \quad$ Ok, bagaimana menyusun persamaannya?

$S G_{05}$ : Disini ada 3 persamaan. Untuk persamaan pertama, kan diketahui edi dan ofi bekerja sama dalam waktu 36 jam kerja sedangkan telah dimisalkan edi adalah $x$ dan ofi adalah $y$, jadi $x$ tambah y sama dengan $\frac{1}{36}$

$P$ : Kenapa $\frac{1}{36}$, kenapa bukan 36 saja?

$S G_{06}$ : $\quad$ Karena 36 jam edi dan ofi bisa menyelesaikan satu pekerjaan. Jadi $\frac{1}{36}$ itu adalah pekerjaan yang bisa dikerjakan edi dan ofi dalam 1 jam.

$P \quad: \quad$ Untuk persamaan kedua dan ketiga?

$S G_{07}$ : Sama kak, dengan cara yang sama didapat persamaan kedua x tambah z sama dengan $\frac{1}{18}$ dan persamaan ketiga y tambah $z$ sama dengan $\frac{1}{24}$.

$P \quad: \quad$ Kemudian bagaimana menerapkan persamaan itu untuk menyelesaikan soal dek?

$S G_{08}: \quad$ Dari ketiga persamaan semuanya dijumlahkan kak.

$P \quad: \quad$ Apa tujuan ketiga persamaan dijumlahkan?

$S G_{09}$ : $\quad$ Tujuan akhirnya kan kak untuk menentukan bagaimana kalau tiga orang tersebut bekerja bersama, jadi dari penjumlahannya nanti didapat x tambah y tambah $z$ berapa kak.

Pada Transkrip 2, menunjukkan bahwa subjek SG mampu menjelaskan langkah-langkah yang dilakukan dalam menyusun rencana pemecahan dengan membuat pemisalan/mendefinisikan variabel $\left(S G_{03}\right)$ dan memanfaatkan hal-hal yang diketahui dari hasil analisis terhadap soal untuk menyusun suatu model/persamaan $\left(S G_{05-07}\right)$ yang selanjutnya dapat diselesaikan secara matematis $\left(S G_{08-09}\right)$.

\section{Tahap Melaksanakan Rencana Pemecahan Masalah}

Berikut ini disajikan jawaban tertulis subjek SG tahap melaksanakan rencana pemecahan masalah. Pada Gambar 2 menunjukkan, subjek SG sudah dapat menerapkan perencanaan yang telah disusun. Disini terlihat bahwa subjek SG memahami maksud penggunaan simbol/variabel dan melakukan perhitungan yang tepat. 


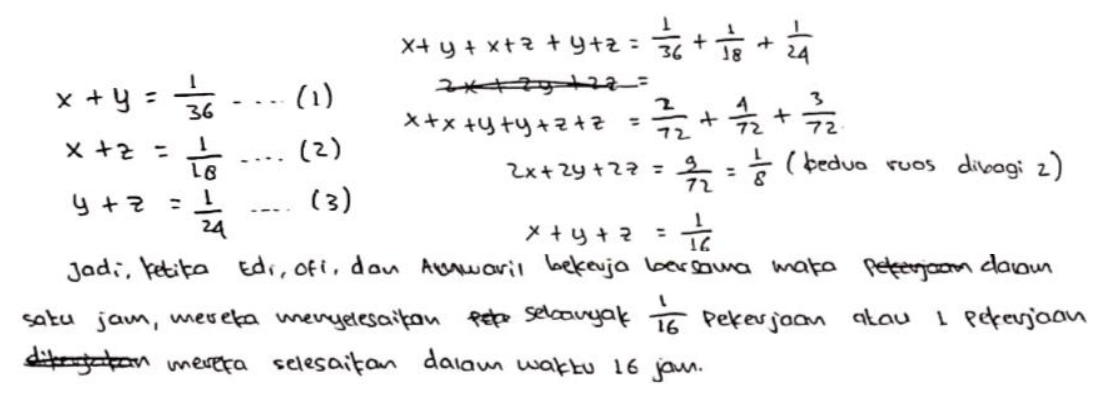

GAMBAR 2. Jawaban subjek SG tahap menyelesaikan masalah

\section{Tahap Memeriksa Kembali}

Berikut ini disajikan petikan wawancara dengan subjek SG tahap memeriksa kembali jawaban.

\section{TRANSKRIP 3}

$P$ : Bagaimana membuktikan jawaban yang diperoleh sudah benar?

$S G_{10}$ : Saya bandingkan waktunya kak. Kalau ketiga-tiganya, edi, ofi dan anwaril bekerja bersama waktu yang dibutuhkan lebih sedikit dibandingkan ketika mereka bekerja berpasangan. Dari situ saya yakin jawaban saya sudah benar.

$P \quad$ : Apa ada cara lain untuk membuktikannya?

$S G_{11}$ : Kalau saya hanya itu kak....Sama itu kak, memeriksa perhitungannya apakah sudah benar semua.

Transkrip 3, menunjukkan bahwa subjek SG memeriksa kembali jawaban dengan melihat kesesuaian antara hasil yang telah diperoleh dengan yang diketahui pada masalah $\left(S G_{10}\right)$ serta memeriksa kembali langkah pengerjaan yang telah dilakukan $\left(S G_{11}\right)$.

Subjek tipe guardian (SG) dapat melakukan setiap tahapan dan indikator pemecahan masalah dari kedua permasalahan yang diberikan berdasarkan langkah Polya dengan baik dan lancar yaitu: (1) menetukan hal-hal yang diketahui dan ditanyakan dari masalah dengan mudah, (2) dapat dengan mudah menentukan pengetahuan pendukung seperti rumus yang berkaitan, kemudian mencari hubungannya dengan hal-hal yang diketahui untuk merumuskan model matematika, (3) melakukan langkah-langkah penyelesaian berdasarkan rencana/strategi pemecahan masalah, dan (4) menelusuri solusi langkah demi langkah pekerjaan yang telah dibuat dan memeriksa kebenaran hasil atau jawaban serta menyimpulkan hasil sesuai permasalahan asal, sehingga bisa dikatakan subjek SG merupakan tipe yang cenderung teliti dalam mengerjakan soal. Subjek tipe guardian (SG) merupakan tipe yang menyukai pengajar yang dengan gamblang menjelaskan materi dan memberikan instruksi yang mendetail, terkadang melakukan diskusi kelompok. Hal ini sesuai dengan metode mengajar yang biasanya diterapkan di sekolah tempat penelitian yaitu metode konvensional dan diskusi, dimana metode ini cocok dengan subjek tipe guardian (SG) sehingga lebih mudah memahami materi dan memiliki pengetahuan awal yang diperlukan dalam memecahkan masalah.

\section{Subjek Tipe Rational (SR)}

\section{Tahap Memahami Masalah}

Berikut ini disajikan hasil tes dan petikan wawancara subjek SR tahap memahami masalah. 


$$
\begin{aligned}
& \text { Dik: } \in d_{i} \text { Jan } O_{f i}=36 \text { Jam ker)a } \\
& \text { ofi dan } a n w a r_{i} l=24 \text { Jan kerja } \\
& \text { Edi Jan anwaril = } 18 \text { jam kerja } \\
& D_{\text {it }}=E d_{1}, \text { ofi dan anwaril .... jam kerja. }
\end{aligned}
$$

GAMBAR 3. Jawaban subjek SR tahap memahami masalah

Pada Gambar 3 terlihat subjek SR menuliskan hal-hal yang diketahui dan hal-hal yang ditanyakan seperti yang dikemukakan pada soal. Untuk mengetahui pemahaman subjek SR tentang apa yang diketahui dan ditanyakan, maka dilakukan wawancara. Cuplikan wawancara subjek SR dijelaskan pada Transkrip 4:

\section{TRANSKRIP 4}

$P \quad$ : Coba jelaskan apa yang diketahui pada soal 2?

$S R_{01}$ : $\quad$ Diketahui waktu yang dibutuhkan Edi dan Ofi adalah 36 jam kerja, Edi dan Anwaril 18 jam kerja, Ofi dan Anwaril 24 jam kerja, dalam suatu pekerjaan.

$P \quad: \quad$ Apa yang ditanyakan di soal?

$S R_{02}$ : $\quad$ Yang ditanyakan, jika Edi, Ofi dan Anwaril bekerja bersama berapa jam waktu yang dibutuhkan untuk menyelesaikan pekerjaan itu.

Pada Transkrip 4, menunjukkan bahwa subjek SR mampu menguraikan dengan benar hal-hal yang diketahui $\left(S R_{01}\right)$ dan hal-hal yang ditanyakan dari soal $\left(S R_{02}\right)$, meskipun penjelasan yang subjek SR berikan cenderung mengikuti kata-kata pada soal.

Tahap Menyusun Rencana Pemecahan Masalah

Berikut ini disajikan petikan wawancara dengan subjek SR tahap menyusun rencana pemecahan masalah.

\section{TRANSKRIP 5}

$P$ : Bagaimana langkah selanjutnya setelah mengetahui hal-hal yang diketahui dan ditanyakan?

$S R_{03}$ : $\quad$ Selanjutnya saya memisalkan dengan $x, y$ dan $z$ dan membuat persamaan.

$P \quad$ : Coba dijelaskan bagaimana pemisalannya, disini tertulis Edi adalah $x$ pekerjaan dalam kurung satu jam?

SR $R_{04}: \quad M a k s u d n y a$ begini kak, Edi menyelesaikan $x$ pekerjaan dalam satu jam. Ofi y pekerjaan dan Anwaril z pekerjaan.

$P \quad: \quad O k$, bagaimana menyusun persamaannya?

$S R_{05}: \quad$ Untuk persamaan pertama, $x$ tambah y sama dengan $\frac{1}{36}$ maksudnya pekerjaan yang diselesaikan jika Edi dan Ofi bekerja sama adalah $\frac{1}{36}$, dalam 1 jamnya kak.

$P$ : Bagaimana dengan persamaan kedua dan ketiga?

$S R_{06}: \quad$ Caranya kak? Hampir sama kak dengan persamaan pertama.

$P \quad: \quad$ Selanjutnya persamaan yang tadi di apakan dek?

$S R_{07}$ : Dijumlahkan kak, setiap yang diruas kiri persamaan dijumlahkan dan ruas kanannya juga semua, tiga persamaan dijumlahkan.

$P \quad$ Kenapa dijumlah?

$S_{08}: \quad$ Kalau sudah dijumlahkan bisa didapat $x$ tambah y tambah $z$, pekerjaan yang diselesaikan tiga orang itu.

Pada Transkrip 5, menunjukkan bahwa subjek SR mampu menjelaskan langkah-langkah yang dilakukan dalam menyusun rencana pemecahan dengan membuat pemisalan $\left(S R_{03-04}\right)$ dan memanfaatkan hal-hal yang diketahui dari hasil analisis terhadap soal untuk menyusun suatu model/persamaan $\left(S R_{05}\right)$ yang selanjutnya dapat diselesaikan secara matematis $\left(S R_{07-08}\right)$. 
Tahap Melaksanakan Rencana Pemecahan Masalah

Berikut ini disajikan jawaban tertulis subjek SR tahap melaksanakan rencana pemecahan masalah.

$$
\begin{aligned}
& x+y=\frac{1}{36} \\
& y+z=\frac{1}{24} \\
& x+z=\frac{1}{18} \\
& 2 x+2 y+2 z=\frac{1}{36}+\frac{1}{24}+\frac{1}{13} \\
& 2(x+y+z)=\frac{2+3+4}{72} \\
& 2(x+y+z)=\frac{9}{72}
\end{aligned}
$$

$$
\begin{aligned}
& 2(x+y+2)=\frac{1}{8} \\
& x+y+z=\frac{1}{16}
\end{aligned}
$$$$
x+y+2=\frac{1}{16} \text { Pekerjaan (sta jam) }
$$

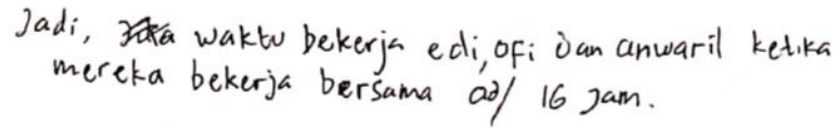

GAMBAR 4. Jawaban subjek SR tahap menyelesaikan masalah

Pada Gambar 4 menunjukkan subjek SR sudah dapat menerapkan perencanaan yang telah disusun. Disini terlihat bahwa subjek SR memahami maksud penggunaan simbol/variable, melakukan perhitungan yang tepat dan bekerja sesuai perencanaan.

\section{Tahap Memeriksa Kembali}

Berikut ini disajikan petikan wawancara dengan subjek SR tahap memeriksa kembali jawaban.

\section{TRANSKRIP 6}

$P \quad: \quad$ Bagaimana meyakinkan kalau jawaban yang diperoleh sudah benar?

$S_{09}$ : Dilihat dari waktunya kak, kalau yang bekerja dua orang dengan yang tiga orang. jika bekerja 2 orang waktunya ada yang 36 jam, 24 jam dan 18 jam, tetapi ketika ketiganya bekerja bersama, waktunya lebih sedikit yaitu 16 jam. Jadi jawabannya sudah benar.

Transkrip 6, menunjukkan bahwa subjek SR memeriksa kembali jawaban dengan melihat kesesuaian antara hasil yang telah diperoleh dengan yang diketahui pada masalah $\left(S R_{\boldsymbol{0 g}}\right)$.

Subjek tipe rational (SR) cenderung praktis (menggunakan cara yang menurutnya paling efektif) dan menggunakan logika dalam mengerjakan soal, dapat melakukan setiap tahapan dan indikator pemecahan masalah dari kedua permasalahan yang diberikan, berdasarkan langkah Polya dengan baik dan lancar seperti subjek SG meskipun dengan perencanaan yang berbeda, meliputi: (1) menetukan hal-hal yang diketahui dan ditanyakan dari masalah dengan mudah, (2) mengaitkan antara hal-hal yang diketahui dengan pengetahuan pendukung lainnya untuk merumuskan model matematika, (3) melakukan langkah-langkah penyelesaian berdasarkan rencana/strategi pemecahan masalah, dan (4) menelusuri kesesuaian antara hasil/solusi yang telah diperoleh dengan yang diketahui pada masalah, kemudian menyimpulkan hasil sesuai permasalahan asal. Subjek tipe rational (SR) merupakan tipe yang mampu menangkap abstraksi, bagus dalam menganalisa, lebih cepat dalam mengamati masalah dan membuat rencana, dan menjalankan rencana/strategi dengan sistematis sehingga dapat menyelesaikan masalah yang diberikan dengan baik.

\section{Subjek Tipe Idealist (SI)}

\section{Tahap Memahami Masalah}

Berikut ini disajikan hasil tes dan petikan wawancara subjek SI tahap memahami masalah. 


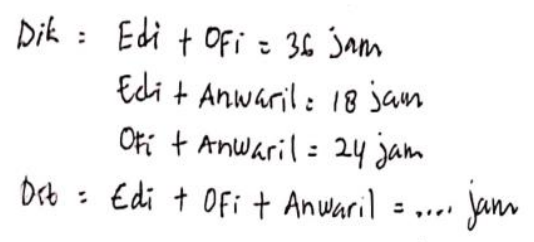

GAMBAR 5. Jawaban subjek SI tahap memahami masalah

Pada Gambar 5 terlihat subjek SI menuliskan hal-hal yang diketahui dan hal-hal yang ditanyakan. Untuk mengetahui pemahaman subjek SI tentang apa yang diketahui dan ditanyakan, maka dilakukan wawancara. Cuplikan wawancara subjek SI dijelaskan pada Transkrip 7 :

\section{TRANSKRIP 7}

$P$ : Coba jelaskan apa yang diketahui pada soal 2?

$\mathrm{SI}_{01}$ : Untuk soal yang kedua ini tentang sistem persamaan linear kan kak, disini diketahui kak, Edi dan Ofi bekerja 36 jam, Edi dan Anwaril bekerja 18 jam, terus Ofi dan Anwaril bekerja 24 jam.

$P$ : Apa yang ditanyakan di soal?

$S_{02}$ : Disini ditanyakan, ketika ketiganya bekerja bersama berapa jam waktu yang dibutuhkan.

Pada Transkrip 7, menunjukkan bahwa subjek SI mampu menguraikan dengan benar hal-hal yang diketahui $\left(S I_{01}\right)$ dan hal-hal yang ditanyakan dari soal $\left(S I_{02}\right)$, meskipun penjelasan yang subjek SI berikan cenderung mengikuti kata-kata pada soal. Subjek SI mengungkapkan bahwa materi yang berkaitan dengan soal adalah sistem persamaan linear $\left(S I_{01}\right)$.

\section{Tahap Menyusun Rencana Pemecahan Masalah}

Berikut ini disajikan petikan wawancara dengan subjek SI tahap menyusun rencana pemecahan masalah.

\section{TRANSKRIP 8}

$P$ : Bagaimana langkah selanjutnya setelah mengetahui hal-hal yang diketahui dan ditanyakan?

$S_{03}: \quad$ Untuk menyelesaikan persamaan linear itu, biasanya dilakukan pemisalan dulu untuk membuat persamaan, dan biasanya pakai x, y, z. Dimisalkan Edi dengan x, maksudnya disini untuk 1 jam pekerjaannya Edi, kemudian Ofi disimbolkan dengan $y$ dan Anwaril dengan z.

$P$ : Maksudnya?

$\mathrm{SI}_{04}$ : Maksudnya disini kak, pekerjaannya Edi dalam 1 jam dimisalkan dengan $x$, Ofi dengan y dan Anwaril dengan z.

$P$ : Sebelumnya kan adek katakan membuat persamaan, nah... bagaimana menyusun persamaannya?

$S_{05}$ : Untuk persamaan pertama, $x$ tambah y sama dengan $\frac{1}{36}, x$ tambah y karena disini Edi dan Ofi bekerja dalam 1 pekerjaan, kemudian $\frac{1}{36}$ maksudnya untuk 1 pekerjaan 36 jam yang dibutuhkan, jadi dalam 1 jam, $\frac{1}{36}$ pekerjaan diselesaikan. Dengan cara yang sama didapat, persamaan dua dan tiga.

$P \quad: \quad$ Selanjutnya persamaan yang tadi itu apakan dek?

$\mathrm{SI}_{06}$ : Dari persamaan satu, dua dan tiga dijumlahkan semua kak, pertanyaannya itu kan bagaimana kalau ketiganya bekerja, jadi berdasarkan pemisalan tadi, yang mau 
dicari $x$ tambah y tambah $z$.

Pada Transkrip 8, menunjukkan bahwa subjek SI mampu menjelaskan dengan gamblang konsep dan langkah-langkah yang dilakukan dalam menyusun rencana pemecahan, subjek SI membuat pemisalan $\left(S_{03-04}\right)$ dan memanfaatkan hal-hal yang diketahui dari hasil analisis terhadap soal untuk menyusun suatu model/persamaan $\left(S I_{05}\right)$ yang selanjutnya dapat diselesaikan secara matematis $\left(S I_{06}\right)$.

\section{Tahap Melaksanakan Rencana Pemecahan Masalah}

Berikut ini disajikan jawaban tertulis subjek SI tahap melaksanakan rencana pemecahan masalah.

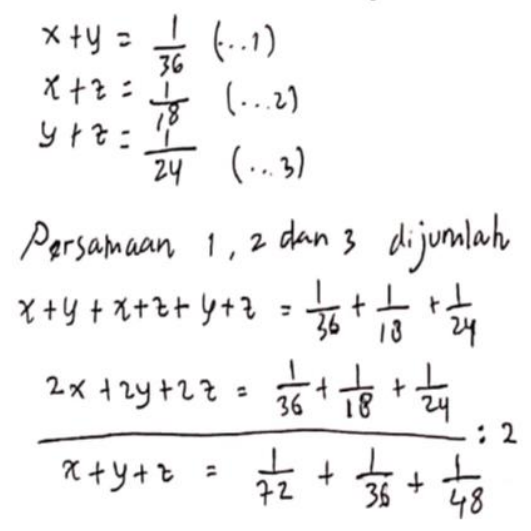

$$
\begin{aligned}
& x+y+z=\frac{2+4+3}{144} \\
& x+y+z=\frac{g}{144}=\frac{1}{16} \\
& x+y+z=\frac{1}{16} \text { pekerjaan }=1 \mathrm{Jam} \\
& 1 \text { Pakerjaan }=16 \mathrm{Jam} \\
& \text { Jadi, waktu Edi } 10 \mathrm{fi} \text { dan Anwaril bekerja sama adalah } \\
& \text { Selesai dalam Wakto } 16 \text { jam. }
\end{aligned}
$$

GAMBAR 6. Jawaban subjek SI tahap menyelesaikan masalah

Pada Gambar 6 menunjukkan subjek SI sudah dapat menerapkan perencanaan yang telah disusun. Disini terlihat bahwa subjek SI memahami konsep yang digunakan untuk menyelesaikan soal, bekerja sesuai perencanaan, dan melakukan perhitungan yang tepat.

\section{Tahap Memeriksa Kembali}

Berikut ini disajikan petikan wawancara dengan subjek SI tahap memeriksa kembali jawaban.

\section{TRANSKRIP 9}

$P$ : Bagaimana membuktikan jawaban yang diperoleh sudah benar?

$S_{07}:$ Hmmm.. tidak tau kak.

$P \quad$ Biasanya bagaimana caranya membuktikan?

$S I_{08}$ : Biasanya kalau soal-soal begini kak yang ditanyakan nilainya $x, y, z$ masingmasing. Jadi mudah membuktikannya, tinggal disubtitusi nilai-nilainya ke persamaan. Tapi kalau seperti ini saya tidak tau kak. Jadi, saya periksa saja kembali langkah dan perhitungannya apakah tidak ada yang keliru.

Transkrip 9, menunjukkan bahwa subjek SI tidak dapat menjelaskan secara prosedural dan konkret bagaimana ia membuktikan kebenaran jawaban $\left(S I_{07}\right)$, subjek hanya menelusuri kembali langkah-langkah penyelesaian dan perhitungan untuk memastikan tidak ada kekeliruan $\left(S I_{08}\right)$.

Subjek tipe idealist (SI) melakukan pemecahan masalah dengan cukup baik, ditunjukkan dengan subjek SI dapat: (1) menetukan hal-hal yang diketahui dan ditanyakan dari masalah, (2) menentukan pengetahuan pendukung yang berkaitan, kemudian mencari hubungannya dengan hal-hal yang diketahui untuk merumuskan model matematika, (3) melakukan langkah-langkah penyelesaian berdasarkan rencana/strategi pemecahan masalah, dan (4) memeriksa kebenaran hasil/solusi, meskipun pada masalah kedua yang diberikan, subjek tidak dapat menunjukkan tahap ini, subjek tidak dapat menunjukkan kebenaran/ kesesuaian antara hasil/solusi yang telah diperoleh dengan yang diketahui. Selanjutnya, subjek menjelaskan atau menginterpretasikan 
hasil sesuai permasalahan asal. Subjek tipe idealist (SI) merupakan tipe yang detail dalam menjabarkan jawabannya baik secara lisan maupun tulisan, lebih menyukai belajar dan menyelesaikan tugas secara pribadi atau individu, belajar mandiri misalnya dengan mencari video di youtube tentang suatu materi matematika dan memahami apa yang diajarkan oleh tutor sehingga lebih banyak waktu yang bisa digunakan untuk fokus pada materi dan mengeksplor pengetahuannya. Dengan demikian subjek tipe idealist (SI) dapat memperoleh pengetahuan awal (pengetahuan pendukung) dan memanfaatkannya dalam pemecahan masalah.

\section{Subjek Tipe Artisan (SA)}

Tahap Memahami Masalah

Berikut ini disajikan hasil tes dan petikan wawancara subjek SA tahap memahami masalah.

$$
\begin{aligned}
& E d_{1} \text { dom } O F_{i}=36 \text { jam kerjs } \\
& \text { Ed: dan Anwaril = } 18 \text { jeonkerja } \\
& \text { of dan Anwan'l = } 24 \text { jorm kerja }
\end{aligned}
$$

GAMBAR 7. Jawaban subjek SA tahap memahami masalah

Pada Gambar 7 terlihat subjek SA menuliskan hal-hal yang diketahui, namun tidak menuliskan hal yang ditanyakan. Untuk mengetahui pemahaman subjek SA tentang apa yang diketahui dan ditanyakan, maka dilakukan wawancara. Cuplikan wawancara subjek SA dijelaskan pada Transkrip 10 :

\section{TRANSKRIP 10}

$P \quad: \quad$ Coba jelaskan apa yang diketahui pada soal 2?

$S A_{01}$ : Untuk sebuah pekerjaan, Apabila Edi dan Ofi bekerja bersama, pekerjaan tersebut akan selesai dalam waktu 36 jam kerja, Edi dan Anwaril dalam jangka waktu 18 jam, terus Ofi dan Anwaril dalam jangka waktu 24 jam.

$P \quad: \quad$ Apa yang ditanyakan di soal?

$S A_{02}$ : $\quad$ Yang ditanyakan, berapa jam yang dibutuhkan Edi, Ofi dan Anwaril untuk menyelesaikan pekerjaan tersebut jika ketiganya bekerja bersama.

Pada Transkrip 10, menunjukkan bahwa subjek SA menyebutkan dengan benar hal-hal yang diketahui $\left(S A_{01}\right)$ dan hal-hal yang ditanyakan dari soal $\left(S A_{02}\right)$, meskipun pada saat memberi penjelasan, subjek SA cenderung membaca soal.

\section{Tahap Menyusun Rencana Pemecahan Masalah}

Berikut ini disajikan petikan wawancara dengan subjek SA tahap menyusun rencana pemecahan masalah.

\section{TRANSKRIP 11}

$P \quad$ : Bagaimana langkah selanjutnya setelah mengetahui hal-hal yang diketahui dan ditanyakan?

$S_{03}: \quad$ Biasanya kak kalau soal cerita seperti ini dimisalkan dulu, biasanya pakai $x, y, z$. Dimisalkan Edi dengan x, Ofi dengan y dan Anwaril dengan z. Lalu dibuat persamaannya.

$P \quad: \quad$ Ok, bagaimana menyusun persamaannya?

$S_{04}$ : $\quad$ Tidak yakin kalau itu kak, karena yang saya tulis itu asal saja, tidak tahu benar atau tidak. Langsung saja kak, kan edi itu $x$ dan ofi itu y sedangkan waktu kerjanya 36 jam jadi $x$ tambah y sama dengan 36. Begitu juga persamaan lain.

$P \quad: \quad$ Misalnya persamaan/model matematika yang tadi itu sudah benar, bagaimana kirakira cara untuk menyelesaikannya, dek? 


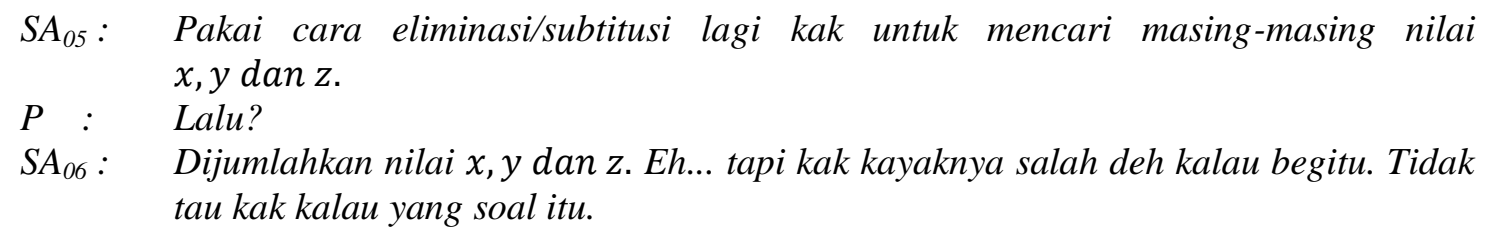

Pada Transkrip 11, menunjukkan bahwa subjek SA tidak memiliki penjelasan konkret terkait dengan perencanaan yang telah disusun, subjek SA menambahkan bahwa ia hanya asal saja dalam menjawab $\left(\mathrm{SA}_{04}\right)$. Hal ini mengakibatkan subjek SA tidak dapat menyelesaikan soal 2 yang diberikan.

\section{Tahap Melaksanakan Rencana Pemecahan Masalah dan Memeriksa Kembali}

Berdasarkan hasil wawancara tahap perencanaan, subjek SA kesulitan untuk menentukan langkah penyelesaian masalah, subjek SA mencoba mengungkapkan pendapatnya mengenai cara yang bisa dilakukan untuk menyelesaikan soal 2, namun subjek SA tidak yakin dan kurang konsep untuk menyelesaikan masalah tersebut $\left(S A_{06}\right)$. Sehingga untuk soal 2 ini tidak ada jawaban yang diperoleh subjek SA. Dengan demikian, tidak ada pula tahap memeriksa kembali jawaban soal 2 oleh subjek SA.

Subjek tipe artisan (SA) cenderung tergesa-gesa dalam mengerjakan soal. Hal ini dilihat dari masih adanya kekeliruan/kesalahan penulisan. Untuk masalah pertama yang diberikan, subjek dapat menetukan hal-hal yang diketahui dan ditanyakan dari masalah, memiliki rencana pemecahan masalah dengan menentukan rumus dan model matematika, menyelesaikan masalah berdasarkan rencana pemecahan masalah, memeriksa kebenaran hasil/solusi, meskipun sempat ada kekeliruan/kesalahan penulisan. Untuk masalah kedua, subjek tidak dapat memecahkan masalah sehingga tidak menemukan solusi, perencanaan yang dilakukan tidak dapat dijadikan pedoman dalam menyelesaikan masalah. Subjek tipe artisan (SA) merupakan tipe yang lebih cepat merasa bosan dengan suasana yang menuntutnya terlalu fokus dan banyak berpikir, cenderung lambat dalam belajar/memahami materi matematika, terbukti pada soal kedua subjek tidak dapat meneruskan untuk menyelesaikan soal. Subjek SA lebih menyukai ilmu terapan dan pengalaman belajar yang melibatkan aksi. Sehingga subjek tipe artisan (SA) kurang mampu dalam pemecahan masalah yang memerlukan analisis.

Hasil penelitian menunjukkan bahwa dari masing-masing subjek yang bertipe kepribadian keirsey, kemampuan pemecahan masalah cenderung pada subjek tipe guardian dan rational. Pada tahapan pemecahan masalah matematika setiap subjek dari empat tipe kepribadian berbeda tersebut cenderung melakukan abstraksi dengan menggunakan simbol dan menggunakan langkah-langkah penyelesaian soal yang umum digunakan, kemudian menyimpulkan hasil/jawaban yang diperoleh berdasarkan permintaan soal (permasalahan).

\section{KESIMPULAN}

1. Siswa yang bertipe kepribadian guardian (subjek SG) dapat melakukan setiap tahapan pemecahan masalah berdasarkan langkah Polya. Subjek SG dapat dengan mudah memahami masalah, menyusun rencana pemecahan masalah, menyelesaikan masalah berdasarkan rencana, memeriksa solusi langkah demi langkah pekerjaan yang telah dibuat dan memeriksa kebenaran hasil atau jawaban serta menyimpulkan hasil sesuai permasalahan asal.

2. Siswa yang bertipe kepribadian rational (subjek SR) dapat melakukan setiap tahapan pemecahan masalah berdasarkan langkah Polya. Subjek SR dapat memahami masalah, menyusun rencana pemecahan masalah, menyelesaikan masalah berdasarkan rencana, dan memeriksa kesesuaian antara hasil/solusi yang telah diperoleh dengan yang diketahui serta menyimpulkan hasil sesuai permasalahan asal. 
3. Siswa yang bertipe kepribadian idealist (subjek SI) dapat melakukan pemecahan masalah berdasarkan langkah Polya. Subjek SI dapat memahami masalah, menyusun rencana pemecahan masalah, menyelesaikan masalah berdasarkan rencana, dan memeriksa kembali hasil atau jawaban meskipun pada permasalahan tertentu tidak dapat menunjukkan kebenaran/kesesuaian antara hasil/solusi yang telah diperoleh dengan yang diketahui serta dapat menyimpulkan hasil sesuai permasalahan asal.

4. Siswa yang bertipe kepribadian artisan (subjek SA) pada permasalahan tertentu yang memerlukan banyak analisis, tidak dapat melakukan tahapan pemecahan masalah Polya, subjek SA tidak dapat menyusun rencana pemecahan masalah, sehingga tidak dapat menyelesaikan masalah tersebut.

5. Berdasarkan hasil pembahasan, siswa tipe guardian (subjek SG) dan tipe rational (subjek SR) lebih dominan, karena dapat melakukan setiap tahapan pemecahan masalah berdasarkan langkah Polya dengan baik dan lancar. Selanjutnya adalah siswa tipe idealist (subjek SI), melakukan pemecahan masalah dengan cukup baik. Yang terakhir adalah siswa tipe artisan (subjek SA) yang tidak dapat memecahkan masalah pada permasalahan tertentu.

\section{DAFTAR PUSTAKA}

Ayadi, F., Chatterjee, A. \& Woldie, M. (2006). Matching Testing Strategi with Student Personality in a Historically Black University. Jurnal of College Teaching and Learning, 3(3). h.87-93.

Hamidah, K. \& Suherman. (2016). Proses Berpikir Matematis Siswa dalam Menyelesaikan Masalah Matematika Ditinjau dari Tipe Kepribadian Keirsey. Al-Jabar: Jurnal Pendidikan Matematika, 7(2). h.243-245.

Hudoyo, H. (1979). Pengembangan Kurikulum Matematika. Surabaya: Usaha Nasional.

Ilmiyana, M. (2018). Analisis Kemampuan Pemecahan Masalah Matematis Siswa Sma Ditinjau Dari Tipe Kepribadian Dimensi Myer Briggs Type Indicator (Skripsi). Universitas Islam Negeri Raden Intan: Lampung

Kasriana, K. (2017). Deskripsi Kemampuan Pemecahan Masalah Trigonometri ditinjau dari Tipe Kepribadian Dan Tingkat Kecemasan Belajar Matematika Siswa Kelas X SMA Negeri 6 Makassar (Tesis). Universitas Negeri Makassar: Makassar.

Keirsey, D. (1998). Please Understand Me II. Temprament Character Intelligence. USA: Prometheus Namesis Book Company

Keirsey, D. (2009). About The Four Temperaments. http://www.keirsey.com. diakses pada tanggal 20 Januari 2019.

Keirsey, D. \& Bates, M. (1978). Please Understand Me. Del Mar, CA: Prometheus Nemesis.

Polya, G. (1957). How to Solve It: A New Aspect of Mathematical Method. New York: Doubleday Anchor Books.

Rahimayanti, T. Y. (2016). Analisis Proses Berfikir dalam Pemecahan Masalah Matematika Polya Siswa Kelas XI SMAN 1 Bangsri Jepara Berdasarkan Tipe Kepribadian (Skripsi). Universitas Islam Negeri Walisongo: Semarang.

Stanick, G. \& Kilpatrick, J. (1988). Historical Perspectives on Problem Solving in the Mathematics Curriculum. Reston, VA: National Council of Teachers of Mathematics. 